Environment Conservation Journal 19 (3) 149-151, 2018

ISSN 0972-3099 (Print) 2278-5124 (Online)

Abstracted and Indexed

\title{
Role of Panchakarma and Yoga in the treatment of Osteoarthiritis
}

\author{
Kaushik Bhanu Priya网, Joshi Rashmi, Supriya, Bhatkoti Mayank and Sharma Uttam \\ Kumar
}

Received: 20.04.2018

Revised: 28.07 .2018

Accepted: 14.09.2018

\begin{abstract}
All our activities of day-to-day life like sitting, standing, jumping, running, walking, bending, stretching, etc depends on the integrity and healthy condition of our joints. We cannot even imagine living easily with painful, swollen and stiff joints. There are many diseases which affects at some or the other part of our life. Many of them give pain and distress, others disturb our living. Osteoarthritis is one such chronic degenerative disease which when afflicts the joints makes one feel that life is definitely a curse. It occurs mainly in weight bearing joints or may also affect other joints. In Ayurveda it is considered as sandhigata vata which can be managed by different panchkarma therapies and medications. Physical activity such as yoga along with panchkarma gives joint more stability and helps in fast healing. Hence rehabilitation of both yoga and panchkarma gives a better approach towards osteoarthritis.
\end{abstract}

Key words: Osteoarthritis, panchkarma therapies, sandhigata vata, rehabilitation.

\section{Introduction}

The term Osteoarthritis is made up of two words i.e., osteo means bones and arthritis means painful inflammation and stiffness of the joints. It is called as sandhigata vata in ayurveda. Sandhigata vata means the invasion and localization of morbid vata or vayu in the joints of the body thereby producing pain, swelling and restricted moments (samhita charak). It is the common form of arthritis. It afflicts millions of people throughout the world. Osteoarthritis occurs when the protective cartilage on the ends of the bones softened due to loss of mucopolysaccharide ground substance and wears down over a period of time (Warner, 1964). This disease can affect and damage any joint in the body. Joints on one side of the body are often more affected than those on the other. Since knee joint, hip joint and inter-vertebral joints are the most common weight bearing joints in the body hence the occurrence of this disease can be commonly seen in these body parts. It gradually worsens with time and no cure exists. Active life, practicing yoga, maintaining healthy weights, effective medicines and treatments may slow the progression Author's Address

Department of Panchakarma, Uttarakhand Ayurved University, Gurukul Campus, Haridwar, India

E-mail.: dr.bhanupriyakaushik22@gmail.com of osteoarthritis and also help to reduce pain and improve the joint function.

\section{Causes of Osteoarthritis (OA)}

The primary cause of Osteoarthritis is damage of cartilage from mechanical stress with insufficient self repair by the joints. Sources of this stress include misalignments of bones caused by congenital or pathogenic causes, mechanical injury, excess body weight, loss of strength in the muscles supporting a joint(Scott , 1978).

\section{Risk factors}

$>$ Hereditary basis - Osteoarthritis is found to have a greater prevalence among siblings and identical twins

$>$ Genetic factors-contributes towards variation in susceptibility towards it.

$>$ Sex - Women are more likely to develop Osteoarthritis

$>$ Age-incidence of OA increases with age

$>$ Previous joint injury- it makes a joint more prone to develop Osteoarthritis

$>$ Obesity- increased body weight damage the weight bearing joints (Scott 1978). 


\section{Kaushik et al.}

\section{Signs and Symptoms of Osteoarthritis (OA)}

$>$ Pain - generally described as a sharp ache or a burning sensation in the associated muscles and tendons.

$>$ Tenderness - pain when light pressure is applied on the joint

$>$ Loss of ability to perform activities

$>$ Loss of flexibility - patient may be unable to move his joint through its full range of motion

$>$ Stiffness - more prominent when patient wake up in the morning or after a period of inactivity

$>$ Swelling - Joints become enlarged associated with inflammatory process.

$>$ Restricted movements -The movements of joints is gradually restricted. Joints may hurt during or after movements. (Warner, 1964).

\section{Sandhi Vata}

Osteoarthritis is called Sandhigata Vata or sandhi vata in Ayurveda. Sandhigata vata means a condition in which morbid vata or vayu is located in the joints and destroys various tissues of joints. Since the disease is caused by vitiated vata, all the foods, life activities which cause aggravation of vata are the causes of sandhigata vata. It is purely a vataja vyadhi described in various ayurvedic texts. Charak while explaining sandhivata said that the vitiated vayu dosha is responsible for dhatu kshaya and in turn produces degenerative changes in different parts of body including joints. When some other etiological factors are associated to the joints the aggravated vayu affects more efficiently to these parts. (Samhita Charak) According to acharya charak, the signs and symptoms of sandhigata vata stated as pain (shula), crepitus of joints (atopa), feeling of balloon on touch (vata purna driti sparsha), swelling (shotha), pain on movement(prasarana akunchanayoho pravrittscha vedana) (Samhita Charak).

\section{Panchakarma in treatment of Osteoarthritis Panchakarma plays an important role in the management of sandhigata vata vis a vis osteoarthritis. Being a vataja vyadhi, vata chikitsa upkarma should be followed in sandhigata vata such as vatashamaka chikitsa and mridu virecha etc.}

Abhyanga (Therapeutic oil massage)

Abhyanga or massage is a procedure of rubbing oil or oily substance over the skin with a specific pressure for a specific time. Massage of the afflicted part is done using medicated oils. It provides significant relief from pain by alleviating the morbid vata dosha and reduces swelling by improving the blood circulation. It nourishes and strengthens the bones, joints and soft tissues and also rejuvenates them.

\section{Kati vasti / Janu vasti}

Kati means low back (Lumbo-sacral region), vasti means pooling or holding any liquid / fluid in a restricted place within a compartment or cabin constructed in that region for specific time with the help of dough made by black gram flour, similarly janu basti is done on same way on the knee joint. Nowadays knee cups of various materials are available for kati vasti and janu vasti purpose.

Taildhara, Pichu, Upnaha are the other measures used in the management of sandhivata.

\section{Virechana (Therapeutic Purgation)}

Virechana is a procedure where some purgative drugs are given to induce purgation after the administration of snehana and swedana (Hridaya Astanga). This is a purification process by which waste metabolites, toxins are removed from each and every tissue and microcirculatory channels of the body. In case of involvement of associated symptoms of pitta in sandhigatavata, virechan can be one of the best treatment modality. In this way the morbid doshas especially pitta and vata are maintained in a state of equilibrium, thus preventing or managing the osteoarthritis.

\section{Basti (Therapeutic Enema)}

Vasti means medicated enemas. Vasti or basti is said to be the best treatment for vitiated vayu, which is the chief culprit in pain games. When vayu is controlled by the action of vasti all the other disturbed body elements fall into rhythm and equilibrium. Vasti strengthens the joints and soft tissues, rejuvenates health, aids fast healing and prevents recurrence. Many times, constipation and accumulation of gases in the abdomen is the cause for joint pain. Virechana and vasti act as effective purgatives and relieve the mentioned conditions.

\section{Medoroga Chikitsa}

Since meda or fat is the immediate precursor of asthi dhatu, treatment and medications to prevent or reduce accumulation of fat in the body should be administered, especially if the patient has a weight putting tendency or is obese. Virechana (therapeutic purgation), lekhana vasti (fat 
eliminating enemas) and udwarthana (massage done with herbal powders in the reverse direction) would provide benefit in reducing the body weight and thereby giving relief in sandhigata vata.

\section{Yoga in treatment of Osteoarthritis}

Yoga is explained as performing of different postural exercise with a controlled method of inhaling and exhaling air. It is an ancient science which comes under ayurveda and maintains health by physical activities (Saraswati Satyananda). Different yoga postures are described in different texts of yoga which plays an important role in management of osteoarthritis. As per American College Of Rheumatology treatment guidelines physical activity is an essential part of the effective treatment of osteoarthritis and rheumatoid arthritis for some yoga poses to prevent joint pain and reduce painful conditions of osteoarthritis are: Tadasana, Chakrasan, Paschimothan Asana, Bhadrasan, Pavanmuktasana, Makrasana, Swastikasana, Bhujangasana, Veerasana, Trikonasana, Katichakara Asana etc (Singh Ramharsha) These poses increase strength, flexibility, and balance the joints hence maintain the proper functioning of the joint and related tissue.

\section{Discussion}

Yoga is proven to help people with arthritis improve many physical and psychological symptoms. Recent scientific studies of people with various types of arthritis show that regular yoga practice can help reduce joint pain, improve joint flexibility and function and lower stress and tension to promote better sleep. Panchakarma provides nutrition to the bone and joints through the medicated oils containing herbs it helps in repairing $\&$ healing joint and surrounding tissues. In one way through yoga the mobility and strength increases and application of both yoga along with panchakarma provides lubrication, prevents degeneration, increases circulation and heals the joint. It is also well known that yoga helps a lot in neutralizing the free radicals which are highly responsible for various degenerative processes in human body. When both are done simultaneously it gives a better approach to manage such joint disorder.

\section{Conclusion}

Osteoarthritis is very common disease of joints which holds the privilege of being a part of almost every family, afflicting at least one or two people of the family. It not only cripples the life of the person suffering from it but also disturbs the life of everyone related to him or her. Prevention becomes the key to get over Osteoarthritis. Hence, panchakarma plays a major role as an adjuvant with yoga in management of osteoarthritis. It helps a lot in rehabilitation of the affected joint of the patient and stops further progress of disease.

\section{References}

Ronald Bodley Scott,1978. Price's textbook of the practice of medicine $12^{\text {th }}$ edition: 945 .

Samhita Charak, 2012. Vd. Vidhyadhar Shukla- Purvardh, sutra sthana chapter 13 Varanasi Chaukhamba Surbharti Prakashan.

Samhita Charak, 2012. Vd. Vidhyadhar Shukla- Purvardh, chikitsa sthana chapter 28 Varanasi Chaukhamba Surbharti Prakashan.

Hridaya Astanga, 2010. Vd Brahmanand Tripathi,sutra sthana chapter 16, Chaukhamba Surbharati Prakashan.

Saraswati,Satyananda Asana Pranayama Mudra Bandha.

Singh Ramharsha. Yoga Evam Yogic Chikitsa Prof., Chaukhamba Surbharti Prakashan, chapter-yogic chikitsa $: 114$. 